\title{
Freezing Tolerance of 27 Saltgrass Ecotypes from Three Cold Hardiness Zones
}

\author{
Hrvoje Rukavina, Harrison G. Hughes ${ }^{1}$, and Yaling Qian \\ Department of Horticulture and Landscape Architecture, Colorado State \\ University, Fort Collins, CO 80523-1173
}

Additional index words. abiotic stress, warm season turfgrass, selection for freezing tolerance, time of turfgrass leaf browning in fall

\begin{abstract}
Freezing is the major abiotic stress that limits geographic distribution of warm season turfgrasses. Prior studies have indicated variation in freezing tolerance in saltgrass clones. Therefore, this study examined freezing tolerance of 27 saltgrass clones as related to collection sites in three zones of cold hardiness. Furthermore, these clones were evaluated for time of leaf browning in the fall with the intent to determine if there was a correlation between this trait and freezing tolerance. Rhizomes were sampled during 2004 and 2005 midwinters from clones established in Fort Collins, Colo., and then subjected to a freezing test in a programmable freezer. Saltgrass freezing tolerance was highly influenced by the climatic zone of clone origin in both years of the experiment. Clones with greater freezing tolerance turned brown earlier in fall in both seasons. Ranking of zones for the average $\mathbf{L T}_{50}$ (lethal temperature at which $\mathbf{5 0 \%}$ of rhizomes died) was: zone 4 , most northern $\left(-17.2^{\circ} \mathrm{C}\right)<$ zone $5\left(-14.4^{\circ} \mathrm{C}\right),<$ zone 6 , most southern $\left(-11.1^{\circ} \mathrm{C}\right)$ in 2004 , and zone $4\left(-18.3^{\circ} \mathrm{C}\right)$, < zone $5\left(-15.7^{\circ} \mathrm{C}\right)<$ zone $6\left(-13.1^{\circ} \mathrm{C}\right)$ in 2005. Clones from northern areas tolerated lower freezing temperatures overall. This likely indicates that freezing tolerance is inherited. Large intraspecific variation in freezing tolerance may be effectively used in developing cold hardy cultivars.
\end{abstract}

Saltgrass [Distichlis spicata (L.) Greene] is a North American native that has only recently been used as a forage crop but only now is being looked at for potential for turf adaptation (Kopec and Marcum, 2001). It is a warm season species with excellent drought and salinity tolerance and commonly appears in salty and alkaline soils throughout the central and western United States (Eppley et al., 1998). With continued population growth and periodic drought in the semiarid western United States, there is an increased public interest in using turf species that can tolerate reduced irrigation and saline soil.

Freezing is the major environmental stress that limits geographic distribution of warm season turfgrass species. Variation in freezing tolerance still exists in most grasses and can be effectively used in breeding (Larsen, 1994). A previous freezing study with six saltgrass clones (Shahha et al., 2003a) indicated variation in freezing tolerance and suggested that freezing tolerance could be associated with origin of clone. Differences in freezing tolerance among cultivars and ecotypes have been found in other warm season turf species such as

\footnotetext{
Received for publication 26 May 2006. Accepted for publication 23 Sept. 2006.

We thank Phillip Chapman for help in data analysis and Leigh Towill for suggestions for the improvement of this manuscript. We also thank Dana Christensen for use of plant material.

${ }^{1}$ To whom reprint requests should be addressed; e-mail hghughes@lamar.colostate.edu.
}

seashore paspalum (Cardona et al., 1997; Cyril et al., 2002), zoysiagrass (Dunn et al., 1999), buffalograss (Qian et al., 2001), and bermudagrass (Anderson et al., 2003). On the other hand, Busey (2003) observed variation in freezing tolerance among st. augustinegrass cultivars at only two of 24 experimental counties in Florida. In a freezing experiment with buffalograss performed in Colorado, cultivars with better freezing tolerance turned brown earlier in fall, whereas those less tolerant remained green until mid-November (Qian et al., 2001). To develop new cultivars for specific geographic locations, it is important to study freezing tolerance in this species. Thus, this 2-year experiment was initiated to examine relative freezing tolerance of 27 saltgrass ecotypes collected in three U.S. zones of cold hardiness but grown in one location and to determine if there is an association between leaf color retention in fall and freezing tolerance.

\section{Materials and Methods}

A total of 27 saltgrass clones collected at different locations in three zones of cold hardiness (USDA zones 4, 5, and 6) were used in this experiment (Table 1). Clones were established in small $(5 \times 5 \mathrm{~m})$ plots on a clay loam with an initial $\mathrm{N}$ content of $23 \mathrm{mg} \cdot \mathrm{kg}^{-1}$ at the Colorado State Univ. Hort. Res. Ctr., Fort Collins, Colo., in July 1998. Each clone had two plots in a randomized complete block design. No fertilizers were applied and the field was mowed once a week at the height of $6 \mathrm{~cm}$. Irrigation was applied once a year in July by flooding the field with $\approx 12 \mathrm{~cm}$ of water. Clones used in this experiment were dug up by a shovel from the semifrozen soil from mid-January to late February in 2004 and 2005 (Fig. 1A, B). At that time, saltgrass clones were fully cold acclimated (Shahba et al., 2003a). The procedure was repeated three successive times in each experimental year. The equivalent of two 1-gallon pots was dug for each clone. After removing soil and inert matter, rhizomes of each clone were washed in cold water and divided into eight groups. Each group of rhizomes was wrapped in moist tissue paper that was then enclosed in aluminum foil. The preparation of samples for freezing was performed in a cold environment. After preparation, samples were subjected to freezing treatment in a thermocontrolled freezer (Tenny Jr. Programmable Freezer; Tenny, South Brunswick, N.J.). Samples were initially left at $-2{ }^{\circ} \mathrm{C}$ for $16 \mathrm{~h}$ to nucleate ice and then linearly cooled at $2{ }^{\circ} \mathrm{C} / \mathrm{h}$. Samples were thawed when temperatures reached $-2,-12,-14,-16,-18,-20,-22$, and $-24{ }^{\circ} \mathrm{C}$. One group of rhizomes of each clone was removed from the freezer when a specific temperature was reached and held at $\approx 5{ }^{\circ} \mathrm{C}$ overnight. After thawing, 10 individual rhizomes $(\approx 2 \mathrm{~cm}$ long with one to two nodes) of each target temperature were planted in a row of Styrofoam cells filled with commercial potting media. Styrofoam trays were then placed under a mist system in the greenhouse. The average temperature in the greenhouse during the experiment was $\approx 21$ ${ }^{\circ} \mathrm{C}$ with a 14-h light period. Mist occurred at 10 -min intervals for $12 \mathrm{~h}$ and was turned off during the night. Clones' survival was evaluated by observing shoot regrowth during

Table 1. Saltgrass clones used in the experiment according to their origin and hardiness zone.

\begin{tabular}{lcl}
\hline Clone & $\begin{array}{c}\text { Cold-hardiness } \\
\text { zone }\end{array}$ & \multicolumn{1}{c}{ Place of origin } \\
\hline 1500 & 4 & Chamberlain, S.D. \\
1650 & 4 & Belle Forche, S.D. \\
1720 & 4 & Ansley, Neb. \\
1840 & 4 & Lusk, Wyo. \\
1870 & 4 & Lusk, Wyp. \\
A1210 & 5 & Denver, Colo. \\
A1240 & 5 & Denver, Colo. \\
A1290 & 5 & Denver, Colo. \\
A1350 & 5 & Denver, Colo. \\
A1370 & 5 & Denver, Colo. \\
A1390 & 5 & Denver, Colo. \\
A1410 & 5 & Denver, Colo. \\
A1490 & 5 & Aurora, Colo. \\
A1500 & 5 & Aurora, Colo. \\
A1530 & 5 & Aurora, Colo. \\
A1650 & 5 & Aurora, Colo. \\
A1860 & 5 & Longmont, Colo. \\
A1970 & 5 & Longmont, Colo. \\
A11070 & 5 & Longmont, Colo. \\
A11230 & 5 & Wellington, Colo. \\
A11260 & 5 & Timnath, Colo. \\
A11370 & 5 & Timnath, Colo. \\
A11380 & 5 & Timnath, Colo. \\
C1120 & 6 & Delta, Colo. \\
C1560 & 6 & Aberdeen, Idaho \\
C1660 & 6 & Humboldt Sink, Nev. \\
C1920 & 6 & De Beque, Colo. \\
\hline & &
\end{tabular}


a 2-month period. The experiment was analyzed as a completely randomized design with three replicates. The logistic regression procedure (proc logistic) of SAS (SAS Institute, 1996) in which the ratio of survived and total number (10) of rhizomes was the function of temperature was used to predict $\mathrm{LT}_{50}$ (lethal temperature resulting in $50 \%$ mortality) for each treatment combination. $\mathrm{LT}_{50}$ (calculated as intercept/slope) was then used as a response variable in a nested mixed model analysis of variance (proc mixed) in SAS. Cold hardiness zones of clones' origin and clones nested within zones were treated as fixed factors, whereas repetitions and interaction between repetitions and zones were treated as random factors in both years. Differences between least squares means were used to compare the levels of factors of interest. To test the effect of year on freezing tolerance, data from both years were merged and two new fixed effects, year and interaction between year and zone, were included in the analysis. Leaf color of clones was visually evaluated in the fall by Dr. Rukavina using a scale from 1 (brown) to 9 (green) as previously described (Qian et al., 2001). Color evaluation was performed in October and November in both experimental years. The relationship between time of leaf browning in fall and saltgrass freezing tolerance $\left(\mathrm{LT}_{50}\right)$ was determined by using regression in SAS.

\section{Results and Discussion}

First year of the experiment (fall 2003 and mid-winter 2004). Cold hardiness zones of clones origin and clones significantly influenced freezing tolerance of saltgrass $(P=$ 0.0002 and $P<0.0001$, respectively), which indicates that variability in freezing tolerance that exists among saltgrass clones could be associated with clones' origin and was likely inherited adaptation. The average freezing tolerance of saltgrass clones $\left(\mathrm{LT}_{50}\right.$ mean values) was significantly different among all three cold hardiness zones of clones' origin. Clones from zone 4 tolerated lower freezing temperatures $\left(\mathrm{LT}_{50}=-17.2^{\circ} \mathrm{C}\right)$ as compared with clones from zone $5\left(\mathrm{LT}_{50}=\right.$ $\left.-14.4{ }^{\circ} \mathrm{C}\right)$. Clones from zone 5 exhibited significantly lower $\mathrm{LT}_{50}$ values than clones from zone $6\left(\mathrm{LT}_{50}=-11.1^{\circ} \mathrm{C}\right)$. $\mathrm{LT}_{50}$ values of saltgrass clones from zone 4 ranged from $-17.8^{\circ} \mathrm{C}$ (clone 1720 ) to $-17.1{ }^{\circ} \mathrm{C}$ (clone 1870 ) with no significant differences among them. A broader range in freezing tolerance was observed for zone 5 with clones' $\mathrm{LT}_{50}$ values ranging from $-17.8^{\circ} \mathrm{C}$ (clone $\left.\mathrm{A} 1290\right)$ to $-11.9{ }^{\circ} \mathrm{C}$ (clone A11370). Clones A1290, A1530, A11070, and A1500 had better freezing tolerance than the other eight clones from zone 5 with the exception of no significant difference in freezing tolerance between clones A1500 and A11380. Clones from zone 6 exhibited the least freezing tolerance. These clones $\mathrm{LT}_{50}$ values ranged from $-12.6{ }^{\circ} \mathrm{C}$ (clone $\mathrm{C} 1120$ ) to $-9.5{ }^{\circ} \mathrm{C}$ (clone C1920). Freezing tolerance of clone $\mathrm{C} 1120$ was better than that of clones $\mathrm{C} 1660$ and
A

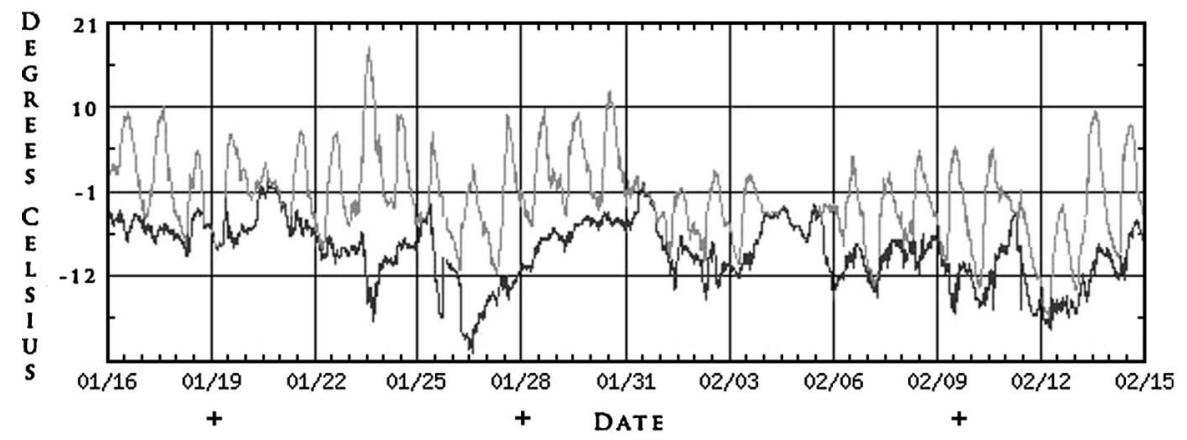

B

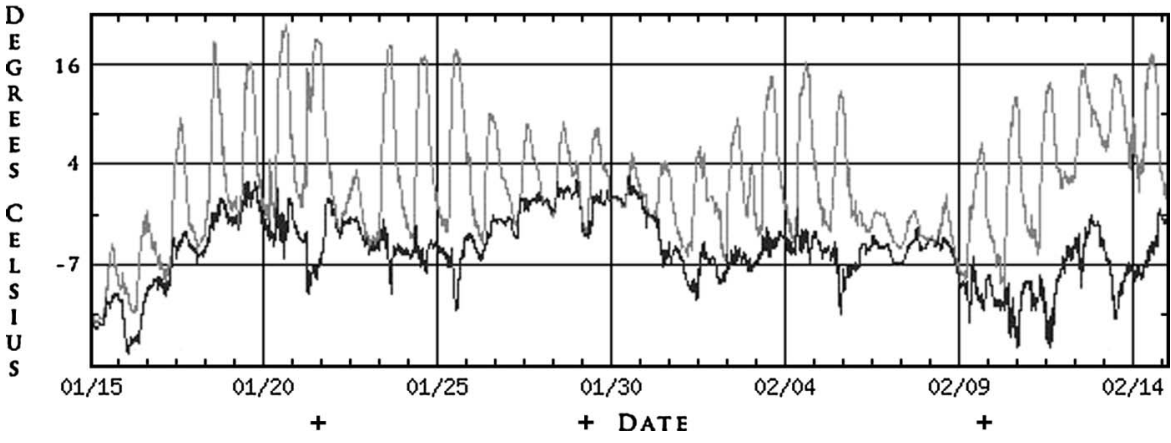

Fig. 1. (A) The minimum and maximum air temperatures in Fort Collins, Colo., from 16 Jan. to 15 Feb. in 2004. Crosses indicate sampling dates. (B) The minimum and maximum air temperatures in Fort Collins, Colo., from 15 Jan. to $15 \mathrm{Feb}$. in 2005. Crosses indicate sampling dates.

A

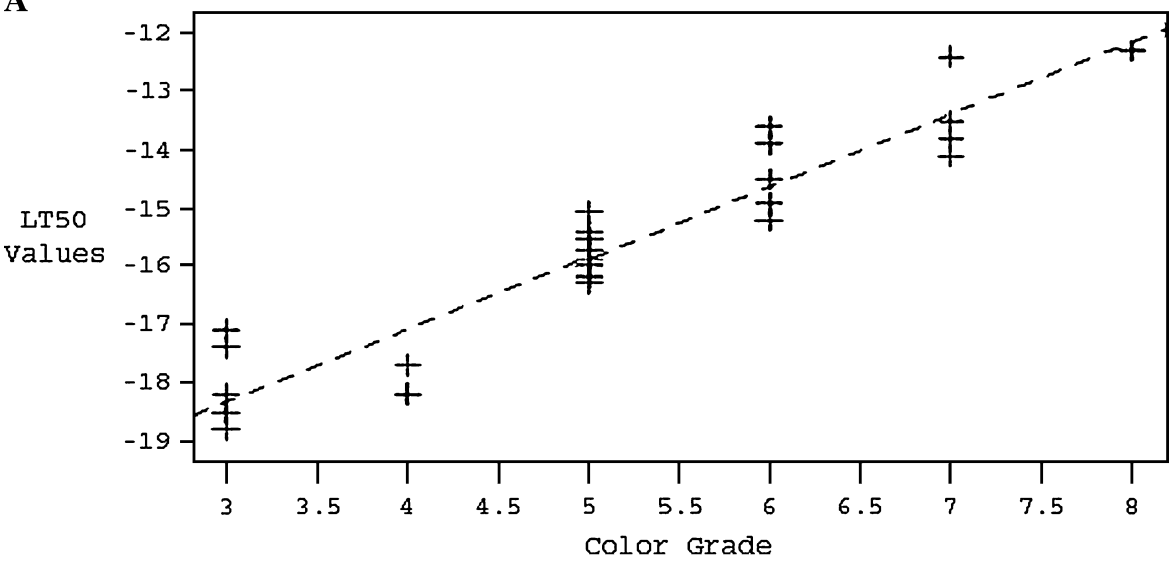

B

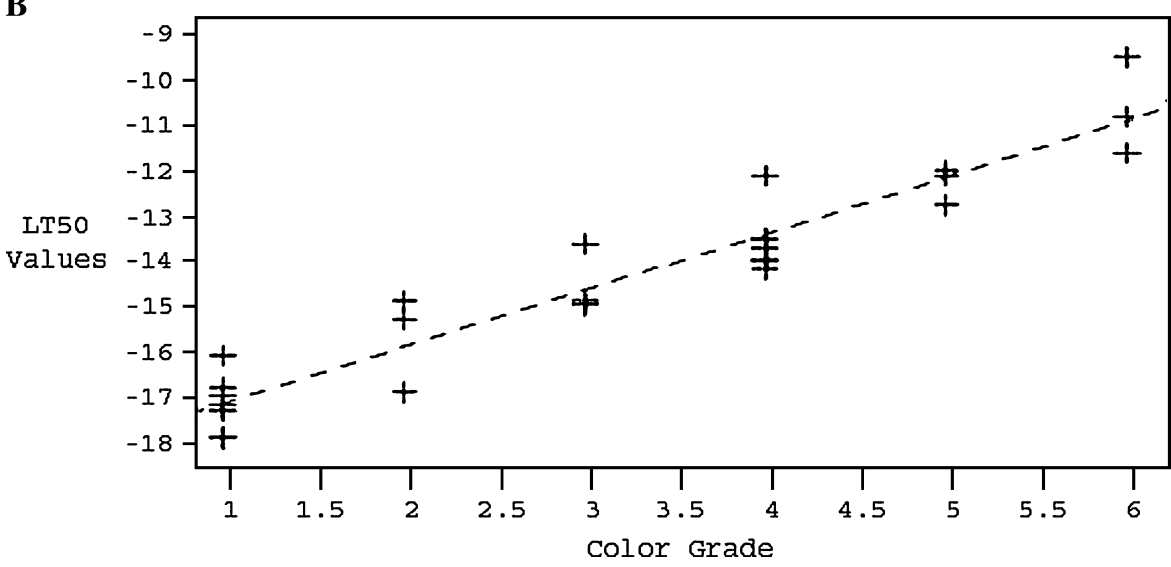

Fig. 2. (A) Linear regression plot of relationship between $\mathrm{LT}_{50}\left({ }^{\circ} \mathrm{C}\right)$ and leaf color retention for 27 saltgrass clones in Oct. 2003. Leaf color was visually evaluated on a 1 to 9 scale in which $1=$ brown and $9=$ green leaf. (B) Linear regression plot of relationship between $\mathrm{LT}_{50}\left({ }^{\circ} \mathrm{C}\right)$ and leaf color retention for 27 saltgrass clones in Nov. 2003. Leaf color was visually evaluated on a 1 to 9 scale in which $1=$ brown and $9=$ green leaf. 
A

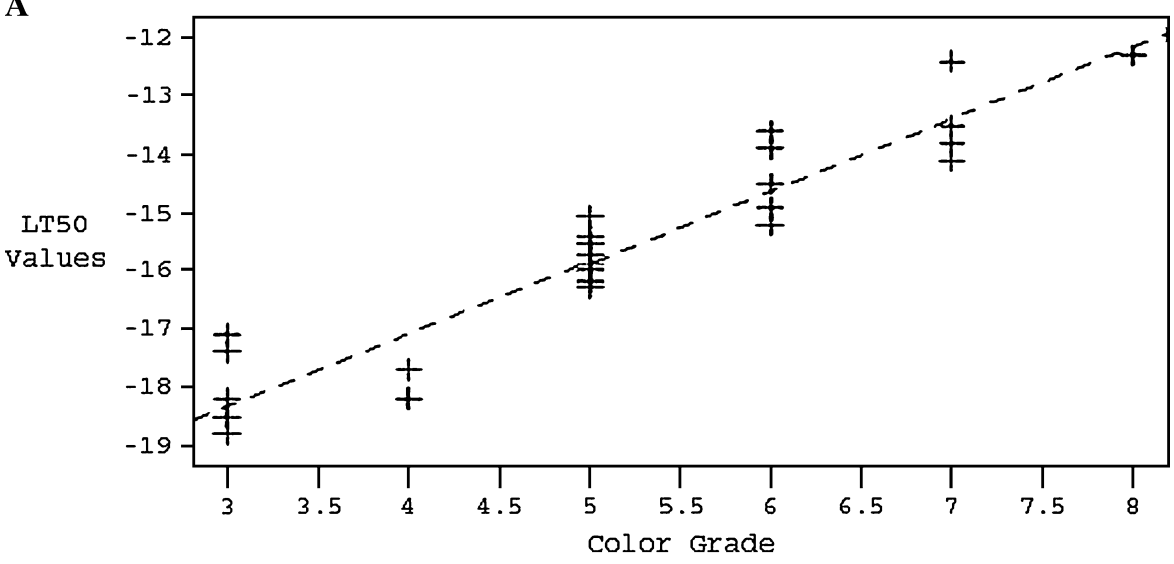

B

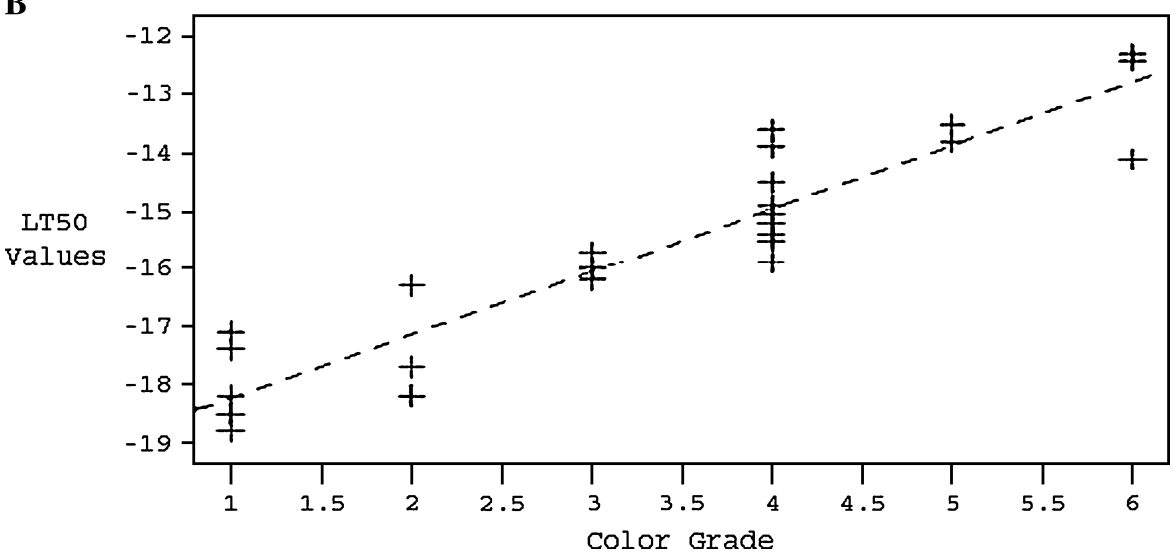

Fig. 3. (A) Linear regression plot of relationship between $\mathrm{LT}_{50}\left({ }^{\circ} \mathrm{C}\right)$ and leaf color retention for 27 saltgrass clones in Oct. 2004. Leaf color was visually evaluated on a 1 to 9 scale in which $1=$ brown and $9=$ green leaf. (B) Linear regression plot of relationship between $\mathrm{LT}_{50}\left({ }^{\circ} \mathrm{C}\right)$ and leaf color retention for 27 saltgrass clones in Nov. 2004. Leaf color was visually evaluated on a 1 to 9 scale in which $1=$ brown and $9=$ green leaf.

C1920. There was no difference in freezing tolerance between clones $\mathrm{C} 1120$ and $\mathrm{C} 1560$. A significant positive relationship between $\mathrm{LT}_{50}$ and fall color retention was determined in October and November of 2003 (Fig. 2A, B). Those saltgrass clones with lower $\mathrm{LT}_{50}$ turned brown earlier (lower color grade scale).

Second year of the experiment (fall 2004 and mid-winter 2005). Saltgrass' freezing tolerance was significantly influenced by climatic zone of clones' origin $(P<0.0001)$ and clones $(P<0.0001)$. These results indicate within species variation in freezing tolerance that is associated with origin of clone. The average $\mathrm{LT}_{50}$ of saltgrass clones was significantly different among zones. These values were slightly lower than those in the first experimental year. Clones from zone 4 had an average $\mathrm{LT}_{50}$ of $-18.3{ }^{\circ} \mathrm{C}$, which was lower than that of clones from zone $5\left(-15.75^{\circ} \mathrm{C}\right)$. Likewise, $\mathrm{LT}_{50}$ values of zone 5 clones were lower than those of clones from zone $6\left(-13.1^{\circ} \mathrm{C}\right)$. Similarly to the first year of the experiment, clones from zone 4 did not significantly differ in freezing tolerance. Their $\mathrm{LT}_{50}$ values ranged from -18.8 ${ }^{\circ} \mathrm{C}$ (clone 1500 ) to $-17.8{ }^{\circ} \mathrm{C}$ (clone 1650 ). Clones from zone 5 again had a broader range of freezing tolerance with $\mathrm{LT}_{50}$ values from
Table 2. Mean values for $\mathrm{LT}_{50}$ of cold hardiness zones in both years of the experiment.

\begin{tabular}{lcc}
\hline Zone & $\begin{array}{c}\mathrm{LT}_{50} \text { values } \\
\left({ }^{\circ} \mathrm{C}\right) \text { in } 2004\end{array}$ & $\begin{array}{c}\mathrm{LT}_{50} \text { values } \\
\left({ }^{\circ} \mathrm{C}\right) \text { in } 2005\end{array}$ \\
\hline 4 & -17.2 & -18.3 \\
5 & -14.4 & -15.7 \\
6 & -11.1 & -13.1 \\
\hline
\end{tabular}

the first experimental year likely reduced the rate of saltgrass cold acclimation and subsequent freezing tolerance. Differences in saltgrass freezing tolerance between 2 experimental years were also found by Shahba et al. (2003a). They explained differences in freezing tolerance as the result of the differences in freezing temperatures in 2 years. Permanently frozen soil during the winter in the first year of research by Shahba et al. (2003a) enabled saltgrass to maintain greater freezing tolerance. Saltgrass freezing tolerance was less in the second year as a result of the cycles of soil freezing and thawing. Significant differences in average $\mathrm{LT}_{50}$ values were found among all three climatic zones of clones' origin in both experimental years. Clones that originated in northern (cooler) areas had greater freezing tolerance than clones from southern (warmer) climates. This supports the suggestion from a previous study (Shahba et al., 2003a) that saltgrass' freezing tolerance is associated with clones' origin. The rank of $\mathrm{LT}_{50}$ values observed in this study is comparable to that reported by Shahba et al. (2003a). Clone A1290 was one of the most cold-hardy clones, whereas clone C1660 was the least cold-hardy in both experiments. Differential response in saltgrass clones' cold tolerance may be related to differences in soluble carbohydrate content in rhizomes. Studies with buffalograss (Ball et al., 2002) and saltgrass (Shahba et al., 2003b) have shown that cultivars and clones with greater freezing tolerance have higher soluble carbohydrate concentration in stolons and rhizomes. Saltgrass freezing tolerance may also be related to unsaturated fatty acids accumulation in rhizomes cell membrane (Cyril et al., 2002), cold-regulated protein (COR) synthesis in rhizomes and crowns (Gatschet et al., 1996), and deep rhizome penetration in the soil (Shahba et al., 2003a). These examples may be the basis for freezing (cold) tolerance in saltgrass but were not evaluated in this study. All clones from cold hardiness zone 4 had similar freezing tolerance. Their adaptation to cooler climates likely enables them to cold acclimate faster and to a higher degree. In general, zone 4 clones became dormant (turned brown) earlier than clones from zone 5 and 6 . This is similar to a study with buffalograss cultivars (Qian et al., 2001). All clones with reduced freezing tolerance retained greater leaf color retention in the fall. In climatic zone 5, considerable variation in freezing tolerance was found among clones in both years of the experiment. These accessions were from the Colorado Front Range and were primarily collected along the I-25 interstate between 
Aurora (a South Denver suburb) and Wellington (north of Fort Collins). Clones A1290, A1500, A1530, and A11070 had the greatest freezing tolerance, whereas clones A1490, A11260, and A11370 exhibited the least freezing tolerance in both seasons. Natural variation among clones in this zone appears to be higher than in the other two zones. Some of these clones may actually be native to other (warmer) areas but accidentally brought to this zone along the highway. Proximity of urban areas that raises environmental temperature might enable survival of these clones as well. However, a broader range of freezing tolerance in zone 5 than in zones 4 and 6 should be taken with caution. There were $\approx 4$ times as many clones sampled from zone 5 than from other zones. Clone numbers in zones 4 and 6 might be too small to represent the actual range of freezing tolerance in these zones. Finally, all four clones in climatic zone 6 exhibited the lowest freezing tolerance in both years. These clones appear to be adapted to warmer climates (Nevada and Southern Colorado) and exhibit greater winterkill in more northern areas. In summary, freezing tolerance is the main environmental factor that limits use of warm season turfgrass species in northern climates and in the transition zone. Our results indicate significant variability in freezing tolerance among saltgrass clones that may be used in the development of cold-hardy cultivars. Time of leaf browning in fall may serve as a selection criterion in breeding for cold hardiness. Freezing tolerance is an environmental adaptation inherited by saltgrass clones associated with specific location. This study indicated that clones from northern (cooler) areas have greater freezing tolerance than those from southern (warmer) climates.

\section{Literature Cited}

Anderson, J.A., C.M. Taliaferro, and D.L. Martin. 2003. Longer exposure durations increase freeze damage to turf bermudagrasses. Crop Sci. 43:973-977.

Ball, S., Y.L. Qian, and C. Stushnoff. 2002. Soluble carbohydrates in two buffalograss cultivars with contrasting freezing tolerance. HortScience 127:45-49.

Busey, P. 2003. Winter survival of st. augustinegrass cultivars. HortScience 38:1439-1440.5.

Cardona, C.A., R.R. Duncan, and O. Lindstrom. 1997. Low temperature tolerance assessment in paspalum. Crop Sci. 37:1283-1291.

Cyril, J., G.L. Powell, R.R. Duncan, and W.V. Baird. 2002. Changes in membrane polar lipid fatty acids of seashore paspalum in response to low temperature exposure. Crop Sci. 42 : 2031-2037.

Dunn, J.H., S.S. Bughrara, M.R. Warmund, and B.F. Fresenburg. 1999. Low temperature tolerance of zoysiagrasses. HortScience 34:96-99.

Eppley, S.M., M.L. Stanton, and R.C. Grosberg. 1998. Intrapopulation sex ratio variation in the salt grass Distichlis spicata. Amer. Nat. 152:659-670.

Gatschet, M.J., C.M. Taliaferro, D.R. Porter, M.P. Anderson, J.A. Anderson, and K.M. Jackson. 1996. A cold-regulated protein from bermudagrass crowns is a chitinase. Crop Sci. 36:712 718.

Kopec, D.M. and K. Marcum. 2001. Desert saltgrass: A potential new turfgrass species. USGA Green Section Record 39:6-8.

Larsen, A. 1994. Breeding winter hardy grasses. Euphytica 77:231-237.

Qian, Y.L., S. Ball, Z. Tan, A.J. Koski, and S.J. Wilhelm. 2001. Freezing tolerance of six cultivars of buffalograss. Crop Sci. 41:1174-1178.

SAS Institute. 1996. JMP for Windows Release 3.1.6.2. Cary, N.C.

Shahba, M.A., Y.L. Qian, H.G. Hughes, D. Christensen, and A.J. Koski. 2003a. Cold hardiness of saltgrass accessions. Crop Sci. 43:21422147.

Shahba, M.A., Y.L. Qian, H.G. Hughes, A.J. Koski, and D. Christensen. 2003b. Relationship of soluble carbohydrates and freeze tolerance in saltgrass. Crop Sci. 43:2148-2153. 